\title{
The Improvement of Caring Behavior among Nurses through Nursing Leadership Based on the Emotional Intelligent
}

\author{
Nur Izzah'1, Agung Waluyo', Dewi Irawaty'1, Mochtarudin Mansyur ${ }^{2}$ \\ ${ }^{1}$ Department of University of Indonesia, Depok, Indonesia \\ ${ }^{2}$ Department of Medicine University of Indonesia, Jakarta, Indonesia \\ Email: izzah.priyogo@yahoo.com
}

How to cite this paper: Izzah, N., Waluyo, A., Irawaty, D. and Mansyur, M. (2018) The Improvement of Caring Behavior among Nurses through Nursing Leadership Based on the Emotional Intelligent. Open Access Library Journal, 5: e4466.

https://doi.org/10.4236/oalib.1104466

Received: March 5, 2018

Accepted: April 15, 2018

Published: April 18, 2018

Copyright $\odot 2018$ by authors and Open Access Library Inc.

This work is licensed under the Creative Commons Attribution International License (CC BY 4.0).

http://creativecommons.org/licenses/by/4.0/

\section{(c) (i) Open Access}

\begin{abstract}
Nursing leadership based on emotional intelligence is potential to improve nurse's caring behavior in Indonesia. The purpose of this research was to find out the effectiveness of nursing leadership based on emotional intelligence of the head nurse and its effect to the caring behavior of the associate nurses. The study occupied quasi experimental design with control group time series in two of General Hospital with equal management system in Pekalongan Regency, Central Java, Indonesia. The nurses of hospital A declared that they were ready to have training while hospital B nurses were not thus they were treated as the control group. Proportional random sampling technique was used for the in-patients department nurses of both hospitals with 44 participants from each. The statistical analysis used general linear model of repeated ANOVA to find out the difference of caring behavior on the intervention group and the control group and to gain the difference caring behavior on each measurement as well as to know the effect of their age and length of working on associate nurse's caring behavior. The result of this study showed the score of the associate nurse's caring behavior on intervention group was higher than the control group with the $P$ value $=0.020$. The increase of the score of associate nurse's caring behavior on intervention group was significant with the mean before and after the intervention were 135.5 and 142.1 respectively, with the $P$ value $=0.003$. There was significant effects of the nursing leadership based on the emotional intelligent with the associate nurse's caring behavior. The nursing leadership based on emotional intelligent was effective to improve associate nurse's caring behavior hence it is recommended to give the training for the implementation.
\end{abstract}

\section{Subject Areas}

Nursing 


\section{Keywords}

Nursing Leadership, Emotional Intelligent, Caring Behavior, Associate Nurse

\section{Introduction}

Nurses are the human resources who put the colors to the health service in the hospital, beside their foremost quantity, nurses also represent the profession which give constant and continuous service to the client for 24 hours a day. The presence of the nurse for 24 hours in the in-patient department gives particular excrescent compare to other health professional. Documentation study did by the researcher in three hospitals in central Java related complains reported by the family through mail box and SMS center and interview, it was found that some nurses were dishonest, unfriendly to the client and the family, less responsive to the client's complaints, their service was under client's expectation and the deficient communication with the client and the family. Furthermore, another study revealed that the time response in one hospital to the client's complaint was 11 minutes.

In nursing practice, some of the deficient points of the nurse mentioned above should not happen, because a nurse ought to have caring behavior to the clients. Caring behavior must be up graded continuously in order to improve their professionalism. Caring is an attitude which shows care, respect, and appreciation to others. Dwiyanti mentioned that caring has the commitment to prevent the upcoming bad events, express of love and bonding, authority and presence, always together, empathy, knowledge, appreciation and pleasure [1].

Giving caring in the simple way is not just a matter of emotional feeling or simple attitude. Caring is giving attention to perform a better care. Caring behavior is purposed and functioned to construct social structure, way of life and culture value of each person which is different from one place to another. Thus caring behavior become significantly important value in affecting the quality of service and client's satisfaction especially in the hospital setting. [2] stated that all the effort to improve the quality of service in the hospital must involve the effort to increase the quality of nursing care which could be accomplished through improving the nursing performance.

Caring is the attitude and behavior that must become part of the nursing professional performance as caring behavior doesn't only can improve client's satisfaction but also can increase the hospital's benefit. However, it isn't an easy way to change the caring behavior of a person in the short time period. Some problems encountered in the hospital related the deficient of caring behavior of the associate nurses were the low level of nursing performance and nursing service satisfaction. One of the causing factor of these problems was less optimal of the head nurse leadership. It was found from the preliminary study done by the researcher about the role of the head nurse as manager. The study find out the 
head nurse' role was insufficient even the guideline of team assignment method available.

Some researches revealed there was a problem in managing associate nurses and the role of the head nurse. It may happen due to the nursing leadership function has not been applied effectively, such as giving motivation, briefing, and decision making related nursing service. To solve those problems, an effort to develop the nursing leadership is vitally needed. The development of the nursing leadership based on the emotional intelligent can give contribution to the nursing practice through nurse's caring behavior improvement as one of the nurse responsibility. [3] stated that there was positive association between emotional intelligent with the nursing practice. This motivate the researcher to conduct the study related the development of the nursing leadership based on the emotional intelligent in order to improve caring behavior of the associate nurse.

\section{Purpose of the Study}

Identifying the evidence of nursing leadership effectivity based on the emotional intelligent of the head nurse and the influence of emotional intelligent based head of the nurse leadership on the associate nurse's caring behavior.

\section{Materials and Methods}

\subsection{Design}

Design of this study was quasi experiment with control group time series. Intervention done in this study was the implementation of nursing leadership based on the emotional intelligent performed by the head nurse of in-patient department who previously attended the training. The training of the nursing leadership based on the emotional intelligent held for three days in the classroom and five days in the ward. Head nurse who implement the nursing leadership based on the emotional intelligent was the one who have been declared passed on the training.

The study occupy quasi experimental with control group time series design in two General Hospital in Pekalongan Regency, Central Java, Indonesia, as both hospital have the equal management system. Hospital A declared ready to have training than Hospital B, thus Hospital B was treated as the control group.

The Intervention given on this study was training on nursing leadership based on the emotional intelligent for the head nurses then caring behavior of the associate nurse after 1,2, and 3 months under the implementation of nursing leadership based on emotional intelligent was assesses using CAT questionnaire. While other group received no intervention but their caring behavior was measured after 1, 2, and 3 months.

\subsection{Population and Sample}

Population in this study was associate nurses working in the in-patient department of Kraton Regional General Hospital, and Kajen Regional General Hospital 
Pekalongan Regency. These two hospitals are located in Pekalongan Regency owned by government thus they have the same policy and management under the Pekalongan Regency authority. By this reason the researcher decided to choose these two hospitals for the study.

Sample in this study divided in two groups. Intervention group included nurses with minimum qualification of diploma and not in the orientation program, whose head nurse had been being trained on nursing leadership based on emotional intelligence and passed the training. Participants of the control group were nurses with the same inclusion criteria, but the nurse manager did not attain the similar training.

This study used proportional random sampling with 44 participants from the intervention group and 44 participants from the control group with hospital matching to prevent the communication among participants which might affect the study result. Matching hospital technique also done based on the participants background who mostly had the same level of educational background, gender, status and culture background. The study conducted in two groups was divided as the following:

Intervention group: participants were the associate nurses of Kraton Regional General Hospital managed under the leadership of the head nurse who had joined the nursing leadership based on emotional intelligent and control group: participant are the associate nurse of the Kajen regional General Hospital under the leadership of the head nurse who did not receive any intervention.

The data collected using questionnaire, done for four times in each group with the time series: before the intervention, 1, 2, and 3 months after the intervention. The questionnaire used for this study is Caring Assessment Tool (CAT) [4] which has been modified by the researcher and has been tested with Cronbach $\alpha$ $=0.926$.

Training of nursing leadership by emotional intelligence was implemented for 3 days in the Hall of Kraton General Hospital, Pekalongan Regency with 5 days of practice. In the implementation of training, researchers had collaboration with one of the nursing educational institution related to the expertise who competent to provide material that had to be submitted. The material presented in the training were: 1) building learning commitment, 2) concept and practice of caring, 3) the practice of caring in nursing, 4) nursing leadership model based on emotional intelligence, develop self-awareness, 5) the practice of self-exploration, 6) self-management, 7) conflict management, 8) establish cooperation and trust, 9) effective and assertive communication.

\subsection{Ethical Consideration}

This study obtained the permission from the ethical committee of the Nursing Science Faculty of University of Indonesia. The researchers guarantee the ethical principles of the study and provide explanation related the study purpose and asked for the participant's agreement before conducting the study. Confidential- 
ity of the participant's data is secured and the researchers had fairly treated all the participants.

\section{Result of the Study}

Table 1 Provides the information of the participants' characteristic from intervention and control group. The participants with Diploma III nursing on intervention group were less than in the control group (intervention group 63.6\%, control group $81.8 \%$ ). The proportion of the male and female from both groups were almost equal (intervention group 68.2\%, control group 70.5\%). most of the participants were married (intervention group 79.5\%, control group 72.7\%) with the mean of age characteristic from both groups were slightly different with the mean of the intervention group is 30.9 and the control group 28.2. Length of working of the participants from the two groups showed differences with mean of the intervention group was 7.8 years and the control group was 5.1 years.

General linear model test done to the intervention and the control group, with the result as described in Table 2.

Statistical analysis result with the general linier model-mixed repeated measurement on caring behavior of the associate nurses on the intervention and control group was $P=0.020$ which means there was significant different between caring behavior of the intervention with the control group. It meant the nursing leadership based on the emotional intelligent effectively improve caring behavior of the associate nurse. Based on the interaction value with $P=0.021$, shows that the interaction was significant. Interaction showed that the different of the score on the $1^{\text {st }}$ measurement to the next measurement on the intervention and the control group was significantly different.

The influence of the nursing leadership based on the emotional intelligent on each group is described in Table 3.

Table 1. Characteristic of the associate nurse from intervention group and the control group Year $2015(\mathrm{~N}=88)$.

\begin{tabular}{|c|c|c|c|c|c|}
\hline \multirow{2}{*}{$\begin{array}{l}\text { Socio demographical } \\
\text { background }\end{array}$} & \multicolumn{2}{|c|}{ Intervention group } & \multicolumn{2}{|c|}{ Control group } & \multirow{2}{*}{$P$} \\
\hline & $\mathrm{N}(\%)$ & Mean (sb) & $\mathrm{N}(\%)$ & Mean (sb) & \\
\hline \multicolumn{6}{|l|}{ Education } \\
\hline Diploma III Nursing & $28(63.6)$ & & $36(88.6)$ & & \multirow{3}{*}{0.056} \\
\hline BSN & $13(29.6)$ & & $3(5.8)$ & & \\
\hline Nurse Profession & $3(6.8)$ & & $5(11.4)$ & & \\
\hline \multicolumn{6}{|l|}{ Gender } \\
\hline Male & $14(31.8)$ & & $13(29.5)$ & & \multirow[t]{2}{*}{0.817} \\
\hline Female & $30(68.2)$ & & $31(70.5)$ & & \\
\hline \multicolumn{6}{|l|}{ Marital status } \\
\hline Unmarried & $9(20.5)$ & & $12(27.3)$ & & \multirow[t]{2}{*}{0.453} \\
\hline Married & $35(79.5)$ & & $32(72.7)$ & & \\
\hline Age & & $30.9(6.0)$ & & $28.2(2.9)$ & $<0.001^{\star}$ \\
\hline Length of working & & $7.7(5.3)$ & & $5.1(2.4)$ & $<0.001^{\star}$ \\
\hline
\end{tabular}

${ }^{*} p<0.05$. 
Table 2. Statistical analysis result of the different of associate nurse's caring behavior on 1 st measurement, 2nd measurement, 3rd measurement and 4th measurement.

\begin{tabular}{ccc}
\hline $\begin{array}{c}\text { Caring behavior of the } \\
\text { associate nurse }\end{array}$ & Mean different $(\mathrm{CI}=95 \%)$ & $P$ \\
\hline Intervention group & & \\
Measurement 1 & $132.3-138.7$ & \\
Measurement 2 & $135.0-142.9$ \\
Measurement 3 & $139.8-146.9$ \\
Measurement 4 & $140.6-147.8$ \\
Control group & \\
Measurement 1 & $129.5-136.4$ \\
Measurement 2 & $131.4-137.2$ \\
Measurement 3 & $133.3-137.8$ \\
Measurement 4 & $129.6-135.6$ \\
\hline
\end{tabular}

${ }^{\star} P<0.05$, Interaction $\mathrm{F}=3.66 P=0.021$.

Table 3. Result of the nursing leadership based on the emotional intelligent on the caring behavior of the associate nurse.

\begin{tabular}{ccccccccc}
\hline & \multicolumn{3}{c}{ Intervention group } & \multicolumn{3}{c}{ Control group } \\
\cline { 2 - 8 } Caring behavior & mean & SD & $P$ & $\begin{array}{c}\text { Partial eta } \\
\text { square }\end{array}$ & Mean & SD & $P$ & $\begin{array}{c}\text { Partial eta } \\
\text { square }\end{array}$ \\
\hline Measurement 1 & 135.5 & 10.5 & $0.003^{*}$ & 0.29 & 132.9 & 11.3 & 0.279 & 0.09 \\
Measurement 2 & 138.6 & 11.8 & & & 134.3 & 9.5 & & \\
Measurement 3 & 143.4 & 11.6 & & & 135.5 & 7.5 & \\
Measurement 4 & 144.2 & 11.8 & & & 132.6 & 9.9 & & \\
\hline
\end{tabular}

${ }^{\star} P<0.05$.

The result of the statistical analysis on Table 3 shows the mean of the caring behavior of the associate nurses on intervention group before the implementation of nursing leadership based on the emotional intelligent was 135.5 and after the implementation on the $2^{\text {nd }}$ measurement which was executed 4 weeks after the intervention is $138.6,3^{\text {rd }}$ measurement ( 8 weeks after the intervention) is 143.4 and the $4^{\text {th }}$ measurement ( 12 weeks after the intervention) is $144.2 . P$ value $=0.003$ which means there is significant influence of the implementation of the study result of the nursing leadership based on the emotional intelligent of the head nurse to the caring behavior of the associate nurse. The partial eta square value shows 0.29 , it explained that nursing leadership based on the emotional intelligent could increase $29 \%$ of the caring behavior of the associate nurse.

The control group showed different result. The mean of the caring behavior on control group on the $1^{\text {st }}$ measurement was 132.9 , fourth week measurement was $134.3,8^{\text {th }}$ week measurement was 135.5 and $12^{\text {th }}$ week measurement was 132.6. The result of the general linear model-repeated measurement test showed 
$p=0.279$. It is concluded that there was no significant influence of the nursing leadership to the caring behavior on the control group.

\section{Discussion}

The participants of this study described in the Table 1 showed the participants from the intervention group $63.6 \%$ of them hold DIII nursing, $68.2 \%$ are female, $79.5 \%$ of them were married with the mean length of working more than 5 years (7.8 years), The Age mean was 30.9 years old. The result of this study is equal to some studies conducted in regional general hospitals in Indonesia with the age range of the participants are 26 - 33 years old, mostly hold diploma III nursing and have been working in the hospital for more than 5 years, and most of them are male [5] [6] [7] [8]. Based on the characteristic of the participants, this study result can be used by other regional general hospital or similar private hospitals in Indonesia.

Result of the study revealed the influence of nursing leadership based on emotional intelligent to the caring behavior of the associate nurse shows significant correlation between nursing leadership based on emotional intelligent with the associate nurse's caring behavior with $P=0.003$. The difference of caring behavior was clearly identified between before the implementation of nursing leadership based on emotional intelligent training with the measurement on 1, 2, 3 weeks after the intervention. A leader who has high emotional intelligent, so he will have the ability to understand and respect other's feeling and have the ability to build thus maintain mutual relationship, have the ability to adapt with the emotion, thought, and attitude according to the situation, and have the ability to identify the problem and solution as well [9] [10] [11].

[12] also stated that one of the important thing in the leadership development in nursing to achieve the success is to develop and improve emotional intelligent. The development of emotional intelligent is a good thing because it contributes the leader to have effective skill. The development of the nursing leadership based on the emotional intelligent significantly improve caring creative factor. It also maintains the faith and hope of associate nurse. This is similar to the Sutikno's opinion [13] that extend the leader with emotional intelligent will be able to generate inspiration which can make a person to be more passionate to the group mission and try to keep focusing to the goal in the middle of a busy daily routine that might blurred the true vision.

The leaders who have emotional intelligent have deep self-awareness so he has deep understanding in evaluating self-emotion, strength, weakness, value and motives [8]. A nursing manager is expected to be capable to improve their self-sensitivity and sensitivity to others [14]. On the other hand, the result of this study is contradict with the study result of [15] that stated there is no significant relationship between communication and nursing performance of the associate nurse in controlling the quality of nursing service in the in-patient department. It might happen when the head nurse doesn't consider the suggestion given by others, and take it as the way others to blame him. The head nurse sometimes 
cannot be a good listener and hurting his staff feeling when expressing his opinion.

[5] stated that low caring behavior of the associate nurse caused by insufficient communication between the head nurse and the staff. The head nurse who implement nursing leadership based on the emotional intelligent also implement caring behavior. Caring behavior of the head nurse is performed by the head nurse through becoming a role model for the associate nurse so they are motivated to implement caring behavior to the client.

Result of this study is similar to the result of [16] who stated that the person who has emotional self-awareness is the person who is able to understand what others feel and why something is exist. The study also proof that nursing leadership based on the emotional intelligent also significantly influence the trusted relationship among the associate nurses. There is different between the trust relationship of the associate nurse before and after the intervention of nursing leadership based on emotional intelligent with the $P$ value $=0.002$. The characteristic of the trust mutual relationship are: compatible, empathy, and warm. The nurse shows empathy by trying to feel what's felt by the client and warm attitude by accepting others positively [17]. Result of this study strengthen the previous study about the implementation of the nursing leadership by emotional intelligent directly contribute to the trust mutual relationship among the associate nurses. The implementation of the nursing leadership based on the emotional intelligent additionally can improve nurse's satisfaction [18].

\section{Conclusion}

There is a significant relationship on the implementation of nursing leadership based on the emotional intelligent with the caring behavior of the associate nurse with the $P$ value $=0.003$. Nursing leadership based on the emotional intelligent of the head nurse is effective to improve caring behavior of the associate nurse with the $P$ value $=0.020$.

\section{Implication on the Nursing Service}

Nursing leadership based on the emotional intelligent has huge implication in nursing service. The study proofed that the head nurse who implement the nursing leadership based on the emotional intelligent can improve the caring behavior of the associate nurse. A nursing leader who implement nursing leadership based on emotional intelligent has good personal ability so he can accomplish the assignments as order and perform the responsibility assigned for him. He also can manage the time, well controlling stress for himself and others, overcoming the internal and external conflict, individually or in group. This is helpful in promoting the achievement of the vision and mission thus tested improving caring behavior of the associate nurse. The improvement of caring behavior after implementation of nursing leadership based on emotional intelligent will increase the client's satisfaction to the nursing service provided by the hospital. Client's satisfaction is one of the indicator of the improvement of the nursing service quality. 


\section{References}

[1] Dwiyanti, M. (2007) Caring Kunci Sukses Perawat/Ners Mengamalkan Ilmu. Hasani, Semarang.

[2] Mulyono, M.H., Hamzah, A. and Abdullah, A. (2013) Faktor Yang Berpengaruh Terhadap Kinerja Perawat Di Rumah Sakit Tingkat III 16.06.01 Ambon. Jurnal $A K K$, 2, 18-26.

[3] Gantzer, A.M. (2011) The Impact of Emotional Intellegence in Nursing Leadership on the Nursing Practice Environment. UMI. Dissertation Publishing, ProQuest LLC, Ann Arbor.

[4] Duffy (2007) Dimensions of Caring: Psychometric Evaluation of the Caring Assessment Tool. Advances in Nursing Science, 30, 235-245. https://doi.org/10.1097/01.ANS.0000286622.84763.a9

[5] Gatot and Adisasmito (2004) Hubungan Karakteistik Perawat. Isi pekerjaan dan Lingkungan Kerja terhadap Motivasi Kerja Perawat di Instalasi rawat Inap, RSUD Gunung Jati Cirebon. Jurnal Makara Kesehatan, 9, 1-8.

[6] Zees, R.F. (2011) Analisis factorbudayaorganisasi yang berhubungandenganperilaku caring perawatpelaksana di ruangrawatinap RSUD Gorontalo. Tesis, FIK UI, Depok.

[7] Roatib, A. (2007) Hubungan Antara Karakteistik Perawat dengan Motivasi Perawat Pelaksana dalam Menerapkan Komunikasi Terapeutik pada Fase Kerja di Rumah Sakit Islam Sultan Agung Semarang. Jurnal Keperawatan Media Ners, 1, 43-47.

[8] Mulyaningsih (2011) Hubungan berpikir kritis dengan perilaku caring perawat pelaksana di RSUD dr Muwardi Surakarta. Tesis, FIK UI, Depok.

[9] Goleman, D. (2007). Kecerdasan Emosi: Mengapa Emotional Intelligence Tinggidaripada IQ. In: Hermay, T., Ed., AlihBahasa, PtGramedia Putra Utama, Jakarta.

[10] Agustian, A.G. (2006) ESQ: Rahasia Suksesmembangun Kecerdasan Emosidan Spiritual. Cetakan Kesepuluh, Jakarta.

[11] Bar-On, R. (2005) The Bar-On Emotional Quotient Inventory (EQ-i): Rationale, Description and Psychometric Properties. In: Geher, G., Ed., Measuring Emotional Intelligence: Common Ground and Controversy, Nova Science Publishers, Inc, Hauppauge, 115-145.

[12] Feather, R. (2008) Emotional Intelligencein Relationto Nursing Leadership: Does It Matter. Journal of Nursing Management, 17, 376-382. https://doi.org/10.1111/j.1365-2834.2008.00931.x

[13] Sutikno, R.B. (2010) The Power of 4 Q for HR and Company Development. PtGramedia Utama, Jakarta.

[14] Tomey, M. and Alligood (2006) Nursing Theorysts and Their Work: Edisi 6. Mosby Elsevier, St. Louis.

[15] Mulyadi (2005) Hubungan Kepemimpinan Efektif Kepala Ruangdengan KinerjaPerawat Pelaksanadalam Pengendalian Mutu Pelayanan Keperawatan di Ruang RawatInap RSKM Cilegon. Tesis, FIK UI, Depok.

[16] Stein, S.J. and Book, H.E. (2011) Ledakan EQ: 15 Prinsip Dasar Kecerdasan Emosional Meraih Sukses. Kaifa Gramedia Utama, Bandung.

[17] Asmadi (2008) Konsep Dasar keperawatan. EGC, Jakata.

[18] Cumming, T. (2008) Organization, Development \& Change. South-Western Engage, USA. 